\title{
Paleodistribution of Neotropical species of Erythroxylum (Erythroxylaceae) in humid and dry environments
}

\author{
Luciana Silva Cordeiro", Francisca Soares de Araújo", Ingrid Koch², André Olmos Simões ${ }^{2}$, Fernando Roberto Martins ${ }^{2}$ \\ and Maria Iracema Bezerra Loiola'
}

Received: February 10, 2017

Accepted: June 26, 2017

\begin{abstract}
Variation in environmental conditions during the Quaternary period served as important filters for the maintenance of vegetation types and for determining the composition of the current biota. We analyzed oscillations in the distributions of different vegetation types in Brazil during the Quaternary period using species of the genus Erythroxylum (Erythroxylaceae) because of the vast heterogeneity of habitats in which they occur. We hypothesized that it would be possible to observe geographically distinct distribution patterns of species of Erythroxylum as a result of the climate changes that occurred during the last glacial maximum (LGM) and in the last interglacial period (LIG) of the Pleistocene. We used bioclimatic variables to elaborate distribution models of 11 species under three scenarios: the current climate, LGM, and LIG. We found four plant distribution patterns in humid and semiarid climates. During the LIG, humid patterns were restricted to northeastern and central-western Brazil, while semiarid conditions maintained plant distributions in the same regions of Brazil where they occur today, although with additionanl occurrences in the northern and central-western portions of that country. During the LGM, all distribution patterns exhibited extensions towards the coast due to the exposure of the continental shelf.
\end{abstract}

Keywords: Brazil, modeling, Paleoclimates, vegetation, Pleistocene

\section{Introduction}

Plant species distributions depend on environmental conditions and the evolutionary characteristics of their lineages, which will delimit their areas of occupation (Willig et al. 2003; Mittelbach et al. 2007). Different regions of the planet show unequal species richness, with the tropics being notably more diverse than other regions (Mittelbach et al. 2007).

The reconstruction of the dynamic interactions between species and the environment over time allows us to understand how individuals and plant populations are influenced by climate changes (Gentry 1982; Haffer 2008).
Abrupt climate changes in the past caused variations in the relative abundances of species within each vegetation type, thus modifying the landscape (Antonelli \& SanMartin 2011). An example of those interactions in the temperate region of North America was the replacement of trees by Arctic life forms during the Plio-Pleistocene, generating a shift from forests to the current tundra vegetation (Bennike \& Boecher 1990). During that same period in the Tropical region, wet tropical forests were replaced by open-canopy vegetations such as savannas and seasonally dry tropical forests (Eiten 1972; Bueno et al. 2016).

The canopy fragmentation that occurred during the Pleistocene in the Neotropics is attributed to more limited

\footnotetext{
${ }^{1}$ Programa de Pós-Graduação em Ecologia e Recursos Naturais, Departamento de Biologia, Universidade Federal do Ceará , Campus Pici, 60451760, Fortaleza, CE, Brazil

${ }^{2}$ Departamento de Biologia Vegetal, Instituto de Biologia, Universidade Estadual de Campinas, 13081-970, Campinas, SP, Brazil

${ }^{*}$ Corresponding author: 1s.cordeiro@yahoo.com.br
} 
precipitation (Portillo-Quintero \& Sanchéz-Azofeifa 2010). This observation is supported by records of Pleistocene events that generated seasonally dry tropical forests (SDTF) in South America (Prado \& Gibbs 1993) and the savannas between Central America and southern Mexico (Marchant et al. 2009).

Climatic phenomena, such as global cooling or warming, aridification, or increasing humidity causes the expansion or contraction of different vegetation types (Arakaki et al. 2011; Hughes et al. 2013). Numerous authors affirm that the Quaternary, specifically the Pleistocene period, contributed significantly to the current distribution of species (Haffer 2008; VanDerWal et al. 2009), and during the Pleistocene twenty cycles of glacial expansion and retraction cause significant changes in regional biotas (Haffer \& Prance 2001).

We chose the genus Erythroxylum to investigate how climatic fluctuations that occurred during the upper Pleistocene influenced the distributions of plant species in Brazil, and to test the hypothesis that current geographic patterns are due to climate changes that occurred during the last glacial maximum (LGM) and the last interglacial (LIG) period of the Pleistocene. The genus Erythroxylum comprises 127 species distributed among various phytogeographic domains in Brazil; 92 of those species occur in humid areas (50 of them unique to humid environments, while the other 42 can tolerate seasonally dry climates) (BFG 2015; Flora do Brasil 2020). For genera like Erythroxylum that show large distributions in different kinds of climates, we expected to see distinct groups of plants specifically associated with different climate types. We also expected to be able to explain the presence of some groups of Erythroxylum otherwise occurring in humid climates but associated with high altitude sites in the northeastern region of that country by analyzing variations in their distributions during the environmental changes that occurred during past geological periods. Finally, we expected that the geological events that contributed to increased semiarid conditions would have imposed unfavorable conditions on most species, limiting their areas of occurrence to small refuges, while milder conditions would increase dispersal to new areas.

\section{Materials and methods}

\section{Species studied, data collection, and georeferenced information}

Eleven species were selected for our study based on the extent of their occurrence (area), vegetation types (species exclusive to humid areas, not exclusive to wetlands, or dry areas), and numbers of data collection points (see Tab. 1).

We consulted the databases of Brazilian herbaria (ASE, BAH, BHCB, BOT, EAC, ESA, FUEL, FURB, HSJRP, NHTSA, HUCPE, HUEFS, HUESB, HVASF, IAC, IPA, INPA, JPB, MAC, MBM, MOSS, PEUFR, R, RB, SP, SPF, SPSF, TEPB, UB,
UEC, UFP, UFRN, and VIES) as well as their international counterparts (MOBOT, NMNH, NYBG) available at the Environmental Information Reference Center - CRIA (speciesLink 2017). Acronyms follow Thiers (2017).

Taxonomic identifications were considered reliable when annotated by specialists in the genus (Maria Iracema Bezerra Loiola, Ayrton Amaral Júnior, Timothy Plowman, James Lucas Costa-Lima, and Luciana Silva Cordeiro). Occurrence data were obtained from exsiccate labels available in the form of spreadsheets in the CRIA (speciesLink 2017). The data were standardized to the WGS84 geodetic datum system according to the format suggested by the Darwin Core specification (http://rs.tdwg.org/dwc/) for data using Geographic Information Systems-GIS. The geographic coordinates of the collection points not already known were obtained indirectly, using the coordinates of the municipalities where they were collected, available using the Geoloc tool (speciesLink 2017). These yielded the numbers of localities of occurrence of each species: Erythroxylum amazonicum (14), E. argentinum (69), E. buxus (24), E. citrifolium (232), E. daphinites (148), E. kapplerianum (12), E. leptoneurum (25), E. macrophyllum (83), E. mucronatum (101), E. myrsinites (82), and E. squamatum (113).

The delimitations of the vegetation types in which each species occurred was obtained from BFG (2015) and Flora do Brasil (2020), in which the authors presented lists of species with known occurrences in Brazil, as well as information concerning their distributions. To delimitate areas of preference (humid or dry vegetation), we used the domains where the species were recorded, based on those proposed by Morrone (2014). This author presented a broad review of Neotropical regionalization, defined detailed domains, and supplied additional and important information (such as citations of endemic species of plants and animals). According to Morrone (2014), Brazil can be divided into two subregions: the predominantly humid Brazilian sub-region (composed of two areas - the Boreal Brazilian and South Brazilian areas); and the humid and dry Chacoan subregion (composed of three areas - the Southeastern Amazonian, Chacoan, and Parana).

\section{Potential niche modeling in paleoclimatic scenarios and the delimitation of geographic patterns}

Modeling plant distributions can predict their occupation of different regions based on environmental (bioclimatic) variables that simulate probable past climatic patterns (Soberón \& Peterson 2005; Batalha \& Miyaki 2011; Werneck et al. 2011). These projections are obtained by compiling information based on simulations of variations of temperature, humidity, and ocean and air mass movements (Otto-Bliesner et al. 2006).

To avoid the redundancy of bioclimatic variables in these models, we used a spatial autocorrelation test implemented in the ENMTools 1.4 program (Warren et al. 


\section{Paleodistribution of Neotropical species of Erythroxylum (Erythroxylaceae) \\ in humid and dry environments}

Table 1. Data on the 13 species selected for the elaboration of the models, with their respective scientific name, section (Schulz 1907), countries of occurrence, vegetation types and additional information taken from the literature or made available by speciesLink (2017)

\begin{tabular}{|c|c|c|c|c|}
\hline Specie & $\begin{array}{c}\text { Section } \\
\text { (Schulz 1907) }\end{array}$ & $\begin{array}{l}\text { Countries of occurrence } \\
\text { (Plowman \& Hensold 2004) }\end{array}$ & Vegetation types & Additional Information \\
\hline $\begin{array}{c}\text { Erythroxylum amazonicum } \\
\text { Peyr }\end{array}$ & Rabdophyllum & $\begin{array}{l}\text { Brazil, Colombia, Ecuador, Guya- } \\
\text { na, Peru, Suriname and Venezuela }\end{array}$ & $\begin{array}{l}\text { Upland Forest } \\
\text { (Loiola 2001) }\end{array}$ & $\begin{array}{l}\text { In sandy or sand-stony soils, at alti- } \\
\text { tudes of } 400-1850 m \text { (Loiola 2001) }\end{array}$ \\
\hline E. argentinum O.E.Schulz & $\begin{array}{l}\text { Archerythro- } \\
\text { xyllum }\end{array}$ & Argentina, Bolivia e Brazil & $\begin{array}{l}\text { Ciliary forest, ombro- } \\
\text { phylous forest, rainforest, } \\
\text { restinga (information } \\
\text { obtained from exsicate } \\
\text { labels speciesLink 2017) }\end{array}$ & $\begin{array}{l}\text { At up } 770 \text { m altitude (information } \\
\text { obtained from exsicatae labels } \\
\text { speciesLink 2017) }\end{array}$ \\
\hline E. buxus Peyr & Rabdophyllum & Brazil e Paraguay & $\begin{array}{l}\text { Cerrado (l.s.), ciliary forest } \\
\text { (Loiola 2001) }\end{array}$ & At up $790 \mathrm{~m}$ altitude (Loiola 2001) \\
\hline E. citrifolium A.St-Hill. & Rabdophyllum & $\begin{array}{l}\text { It occurs from Mexico to the } \\
\text { south of Brazil }\end{array}$ & $\begin{array}{l}\text { Ombrophylous forest with } \\
\text { records also for cerrado } \\
\text { (l.s.), ciliary forest and } \\
\text { semi-deciduous seasonal } \\
\text { forest (Loiola 2001) }\end{array}$ & $\begin{array}{l}\text { In sandy or clayey soils, stony or } \\
\text { not, at altitudes between 100-2200 } \\
\text { m (Loiola 2001) }\end{array}$ \\
\hline E. daphinites Mart. & Rabdophyllum & Bolivia and Brazil & $\begin{array}{l}\text { Cerrado (l.s.), ciliary } \\
\text { forest, rock field (Loiola } \\
\text { 2001) }\end{array}$ & $\begin{array}{l}\text { In sandy-clayey, alluvial or stony } \\
\text { soils, between 160-840m altitude } \\
\text { (Loiola 2001) }\end{array}$ \\
\hline E. kapplerianum Peyr & $\begin{array}{l}\text { Archerythro- } \\
\text { xyllum }\end{array}$ & $\begin{array}{c}\text { Brazil, Colombia, French } \\
\text { Guyana, Guyana, Suriname and } \\
\text { Venezuela }\end{array}$ & $\begin{array}{l}\text { Forest of igapó and forest } \\
\text { of floodplain (information } \\
\text { obtained from the labels of } \\
\text { exsicatas speciesLink 2017) }\end{array}$ & $\begin{array}{c}\text { In sandy soils (information } \\
\text { obtained from exsicatae labels } \\
\text { speciesLink 2017) }\end{array}$ \\
\hline E. leptoneurum O.E.Schulz & $\begin{array}{l}\text { Archerythro- } \\
\text { xyllum }\end{array}$ & Brazil and French Guyana & $\begin{array}{l}\text { Ciliary forest and upland } \\
\text { forest (information } \\
\text { obtained from the labels of } \\
\text { exsicatas speciesLink 2017) }\end{array}$ & $\begin{array}{l}\text { In clayey or sandy soils (informa- } \\
\text { tion obtained from the labels of } \\
\text { exsicatae speciesLink 2017) }\end{array}$ \\
\hline E. myrsinites Mart. & Rabdophyllum & $\begin{array}{l}\text { Argentina, Brazil, } \\
\text { Paraguay and Uruguay }\end{array}$ & $\begin{array}{l}\text { Ciliary forest and om- } \\
\text { brophylous forest (Loiola } \\
\text { 2001) }\end{array}$ & $\begin{array}{l}\text { Frequently associade overflow } \\
\text { environments with Frequentemente } \\
\text { associada a ambientes alagados with } \\
\text { forest and floodplains (Loiola 2001) }\end{array}$ \\
\hline E. squamatum Sw. & Rabdophyllum & $\begin{array}{c}\text { It occurs from the Antilles } \\
\text { to South America (except } \\
\text { Argentina, Chile, Paraguay and } \\
\text { Uruguay) }\end{array}$ & $\begin{array}{l}\text { Cerrado (l.s.), ciliary forest, } \\
\text { semi-deciduous seasonal } \\
\text { forest and mbrophylous } \\
\text { forest (Loiola 2001) }\end{array}$ & $\begin{array}{l}\text { Ranging from 100-1600m altitude } \\
\text { (Loiola 2001) }\end{array}$ \\
\hline
\end{tabular}

2010). When two or more variables were strongly correlated, we selected the variable with greatest ecological relevance. The bioclimatic variables (bios) used for the formulation of these scenarios are listed in Table 2 . The bios referring to the last glacial maximum (LGM; $21 \mathrm{kyr}$ BP) were obtained from the Community Climate System Model - CCSM, provided by the Palaeoclimatic Modelling Intercomparison Project (http: //pmip.lsce.ipsl.fr/). The definition of the last biosphere interglacial period (LIG; $130 \mathrm{kyr}$ BP) was based on OttoBliesner et al. (2006). We compared the models generated for LGM and LIG with models based on current climate information (Hijmans et al. 2005) available at the WorldClim site (http://worldclim.org/). Although prepared by distinct groups, all climate scenarios are available on the WorldClim website (http://www.worldclim.org/).

The map of Brazilian territory was obtained from the website of the Brazilian Institute of Geography and Statistics (IBGE 2017). Modeling was performed in two programs:
MaxEnt 3.3.3 (Phillips et al. 2006) and Open Modeller 1.5 (Muñoz et al. 2009). We used three algorithms to generate the models: BIOCLIM (Nix 1986), Genetic Algorithm for Rule Set Production - GARP with best subsets (Anderson et al. 2003) implemented in the Open Modeler program, and Maximum Entropy (Phillips et al. 2006) with the MaxEnt program. In presenting the results, we selected the consensus model.

Using algorithms with different types of performances facilitates the construction of a consensus model with high precision. BIOCLIM is a simpler algorithm than the others, and can be used to define the limits of the areas occupied by focal species without precise definitions of their confidence intervals of occurrence (Nix 1986; Marco-Junior \& Siqueira 2009).

The GARP algorithm, like the other genetic models, generates an ecological niche model of a species through a set of rules that consider its points of occurrence as 
Table 2. Acronyms and significance of environmental variables used in the study, according to the site of WorldClim (http://www. worldclim.org/past).

\begin{tabular}{|c|c|}
\hline Acronymos & Significance \\
\hline bio 1 & Annual Mean Temperature \\
\hline bio 2 & Mean Diurnal Range \\
\hline bio 3 & Isothermality \\
\hline bio 4 & Temperature Seasonality \\
\hline bio 5 & Maximum Temperature of Warmest Month \\
\hline bio 12 & Annual Precipitation \\
\hline bio 13 & Precipitation of Wettest Month \\
bio 14 & Precipitation of Driest Month \\
\hline
\end{tabular}

"individuals" and a set of rules that consider a "population". As they use presence/absence data, the rule predictions function as "genes" that can undergo "mutations" during the execution of the algorithm (Lima-Ribeiro \& Diniz-Filho 2012), which makes the model more precise in terms of the areas of true occurrence.

Maxent (Maximum Entropy algorithm) considers only presence data, and incorporates a learning technique that estimates the distribution probability under the constraints of each environmental variable correlated with species points of occurrence. This analysis generates a more precise model for incompletely known distributions in relation to the total area that should be occupied by a given species (Elith et al. 2011; Phillips et al. 2006).

Using the three algorithms, we developed models using $80 \%$ of the occurrence data to train the models, and 20 $\%$ to test them, with 1000 replications and bootstrap resampling. We selected the values of the receiver operating characteristic curve (ROC curve) for all algorithms that represented areas under the curve (AUC) greater than 0.90 (Fawcett 2003).

The choices of species patterns with similar distributions for each period analyzed were made based on visual observations of stable presence areas. Thus, suitable regions were areas where the habitat remained favorable to the species during all three scenarios analyzed: the current climate, the last glacial maximum (LGM), and the last interglacial (LIG).

\section{Mapping the consensus model solution}

To elaborate the maps of the consensus models, vectors of ensemble frequencies of occurrence of the species were prepared for each of the model combinations per algorithm. The confusion matrix expressing matches and mismatches of observed and predicted occurrences in the validation data set were calculated for each model. The matrix was computed after using ROC curves to convert continuous predictions into presence-absence entries. Models with True Skill Statistics (TSS) smaller than zero were discarded. It was not possible to fit all methods for all species using different combinations of variables (Diniz-Filho et al. 2009).

\section{Results}

Four distinct distribution patterns during Quaternary climate changes were indicated from the models generated. Three patterns occurred preferentially in humid climates (Amazonia, Miscellaneous and South Paraná) and one pattern occurred in seasonally dry climates (Seasonal Dry), see Table 3.

The Amazonian pattern (Fig. 1) comprises the distributions of species whose occurrences are almost exclusively restricted to the Boreal Brazilian, South Brazilian, and South-Eastern Amazonian domains. This pattern was observed for the species Erythroxylum amazonicum, E. kapplerianum, and E. macrophyllum, the latter also occurring in the Chacoan domain. The LIG models represent the smallest occupied areas for this group of species, forming small refuges, and indicating a disjunction in the past between the northern and northeastern regions (the currently drier region). We note here that a small area in the south of the Southeastern Amazonian domain (border between the states of Mato Grosso and Tocantins) harbored all three species during the LIG. During this period, the areas occupied by those species areas were partly displaced to the central-western, northeastern, and southeastern regions of

Table 3. List of patterns and species of Erythroxylum analyzed, with information on phytogeographic domains (Morrone 2014) and vegetation types (BFG 2015; Flora do Brasil 2020) where they were recorded.

\begin{tabular}{|c|c|c|}
\hline Pattern & Specie & Phytogeographic domains (Morrone 2014) \\
\hline Amazonian & Erythroxylum amazonicum & Boreal Brazilian, South Brazilian, Southeastern Amazonian \\
\hline Amazonian & Erythroxylum kapplerianum & Boreal Brazilian, South Brazilian, Southeastern Amazonian \\
\hline Amazonian & Erythroxylum macrophyllum & Boreal Brazilian, South Brazilian, Chacoan, Southeastern Amazonian \\
\hline Miscellaneous & Erythroxylum citrifolium & Boreal Brazilian, South Brazilian, Chacoan, Parana, Southeastern Amazonian \\
\hline Miscellaneous & Erythroxylum mucrontaum & Boreal Brazilian, South Brazilian, Chacoan, Parana, Southeastern Amazonian \\
\hline Miscellaneous & Erythroxylum squamatum & Boreal Brazilian, South Brazilian, Chacoan, Parana, Southeastern Amazonian \\
\hline South Parana & Erythroxylum argentinum & Chacoan, Parana \\
\hline South Parana & Erythroxylum myrsinites & South Brazilian, Chacoan, Parana \\
\hline Seasonal Dry pattern & Erythroxylum buxus & Chacoan, Parana \\
\hline Seasonal Dry pattern & Erythroxylum daphinites & Boreal Brazilian, Chacoan, Parana, Southeastern Amazonian \\
\hline Seasonal Dry pattern & Erythroxylum leptoneurum & Boreal Brazilian, South Brazilian, Chacoan, Parana, Southeastern Amazonian \\
\hline
\end{tabular}




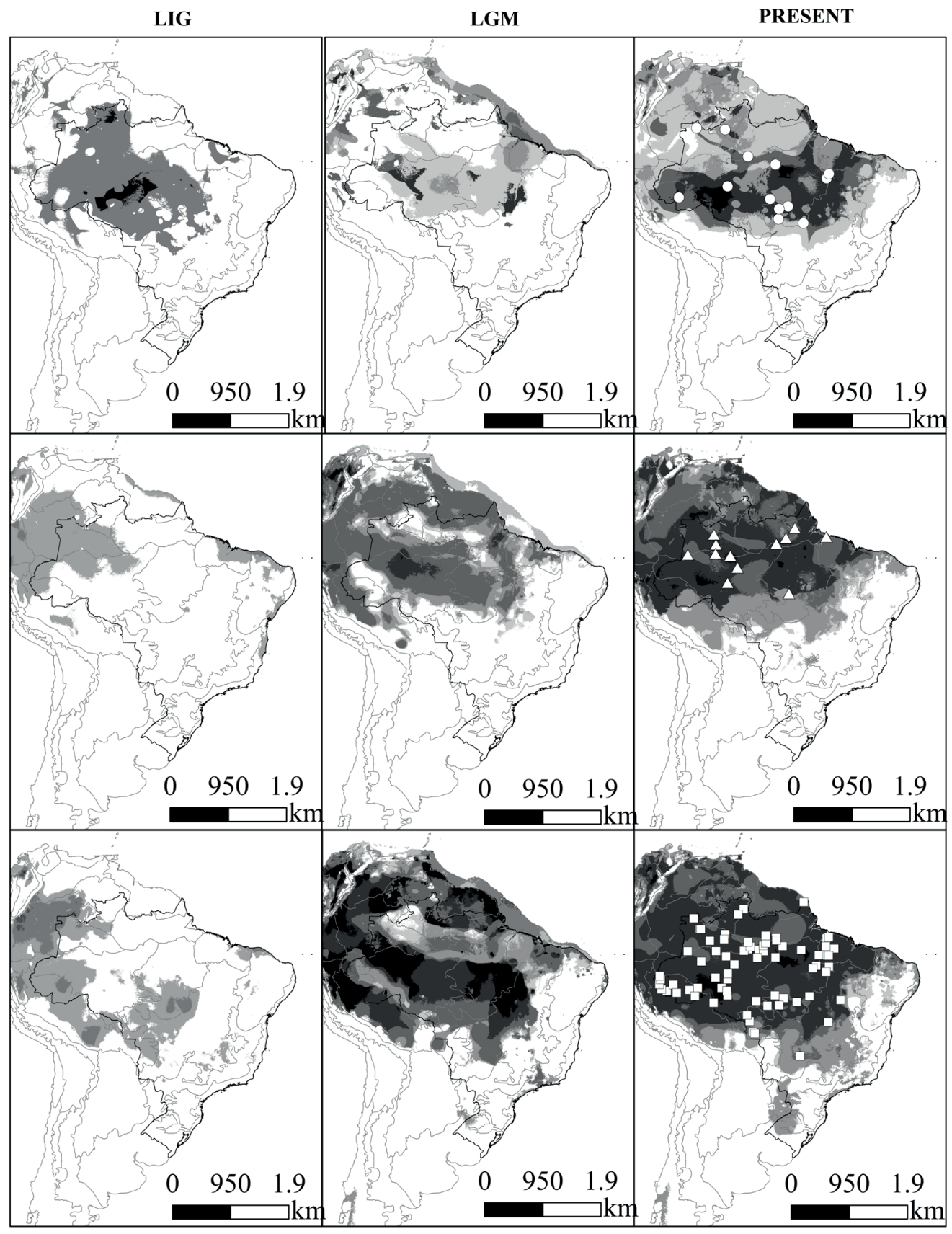

\section{Legend}

\begin{tabular}{|c|c|c|}
\hline \multicolumn{2}{|c|}{ Species } & $0-0.17$ \\
\hline o & Erythroxylum amazonicum & $0.17-0.33$ \\
\hline$\triangle$ & Erythroxylum kapplerianum & $0.33-0.5$ \\
\hline \multirow[t]{3}{*}{$\square$} & Erythroxylum macrophyllum & $0.5-0.67$ \\
\hline & & $0.67-0.83$ \\
\hline & & $0.83-1$ \\
\hline
\end{tabular}

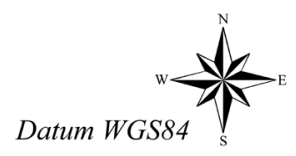

Figure 1. Amazonian pattern with predominance of subtropical wet vegetation under LIG conditions ( 130 Kyr BP), LGM ( 21 Kyr BP) and Present (current climate). The gray gradient represents the probability of occurrence between values of $0-1$. Low values represent less probability of occurrence and higher values, more probability. 
the country. E. amazonicum showed greater similarity with E. macrophyllum in terms of the area it occupied than with E. kapplerianum, possibly due to the similarities between the vegetative types of the former two species. There was an eastward expansion during the LGM (due to decreasing sea levels and consequent exposure of the continental shelf) as well as to the northern region (resembling the current distribution). During this period, the other previously occupied areas were not evidenced. We observed two new areas of high concentrations for the species in the states of Amazonas and Pará. For the current climate, we observed the greatest extension in their areas of occurrence within the area defined as the "Legal Amazon" in all three scenarios. The three species footprints expanded northward, highlighting the model generated for E. amazonicum, indicating a vast collection area little explored for the species (with lower numbers of collection points among the sources surveyed).

The Miscellaneous pattern (Fig. 2) shows diffuse occurrences in all Brazilian phytogeographic domains, with species distributed in both humid (Rainforest, Upland Forests, Ombrophilous Forests) and seasonally dry climates (Seasonal Deciduous Forests and Savannas) at elevations above $80 \mathrm{~m}$. This pattern is represented here by the species Erythroxylum citrifolium, E. mucronatum, and E. squamatum. Compared with their current distributions, the LIG distribution stands out for having significant abundance centers for the period: in the central-west (Mato Grosso do Sul) and north (Amazonas and Acre), as well as in a continuous area near the coast in northeastern and southeastern Brazil. We observed the highest concentrations of areas of occurrence of E. citrifolium during this period (in the northern part of that country and along the coast). E. mucronatum showed a more intense distribution in the northern portion of the Caatinga (current region of savannas), while Erythroxylum squamatum had stronger areas of presence in the central-western region of the country. During the LGM, the center of dense occurrence in the central-west collapsed and the areas of distribution, once extending to the north, became restricted to Acre State. The species were then concentrated near the northeast and southeast coasts of the country, with population increases occurring in environments under coastal marine influence. During the LGM, three regions showed dense populations: in northern Pará, northern Minas Gerais, and southern Bahia. As in the other projections, the species migrated to exposed areas of the continental shelf. It is worth noting, however, that despite being found throughout the country, new areas of colonization occurred only in the north. Under the current climate, the greatest extension of occupied areas generated centers of diffuse richness throughout the country (especially along the northeastern and southeastern coasts), with populations occupying humid and sub-humid forests, Amazonas State (with a new, previously unobserved region with the presence of all of the species), and northern
Minas Gerais, a region under the influence of a seasonally dry climate.

The South Paraná pattern (Fig. 3) was represented by species with essentially exclusive occurrence in Subtropical Rainforests (below the Tropic of Capricorn). Two species are included in this pattern: Erythroxylum argentinum and $E$. myrsinites. This pattern demonstrated the least fluctuation in location and in concentrations of areas of occurrence. During the LIG, both species had distributions marked by smaller disjunctions in the north, with the largest areas of occurrence in the southern region of Brazil. Also during that period, E. argentinum showed a continuous distribution from the northeastern to southern coast. During the LGM, the areas of occurrence in the north disappeared, with those species showing extended distributions towards the coast in the south and southeast due to the exposure of the continental shelf. This greater extension along the coast may have favored the expansion of populations in the coastal regions of the northeast. Under the current climate, there are no populations of E. argentinum situated above the Tropic of Capricorn, leaving only subtropical occurrences; the disjunction with the northeastern coast remains with E. myrsinites. Nonetheless, the models suggest the highest probability of occurrence in the Subtropical Atlantic Rainforest for both species.

The Seasonal Dry pattern (Fig. 4) consists of vegetation types exposed to seasonally dry (sub-dry to dry) climates in all of the domains analyzed (except Brazilian Boreal, which is the most humid domain among those analyzed). Three species were analyzed to illustrate that pattern (E. buxus for the Paraná and Chacoan domains, E. daphinites for the South Brazilian, Southeastern Amazonian, Paraná, and Chacoan domains, and E. deciduum for the Southeastern Amazonian, Paraná, and Chacoan domains). The Seasonal Dry pattern saw no shared areas among the species in the three different scenarios, due to the diversity of vegetation types in the different domains. However, we observed similarities in the expansion and contraction of areas for each scenario. The LIG was the period that showed the most dissimilarity between the species distributions, with $E$. buxus being most likely to occur throughout the country while E. deciduum was restricted to a narrow area in the northeastern and southeastern regions of that country, extending beyond its current area of occurrence. During that same period, E. daphinites was the only species that retained areas with high probability of occurrence where it is currently observed. During the LGM, all three species showed expanded distributions toward the coast near their current areas of occurrence (Erythroxylum buxus and E. deciduum in southern and southeastern Brazil, and E. daphinites in the north). Under the current climate, the species' distributions are reduced, in relation to the LGM, to a continuous strip of land running along the 


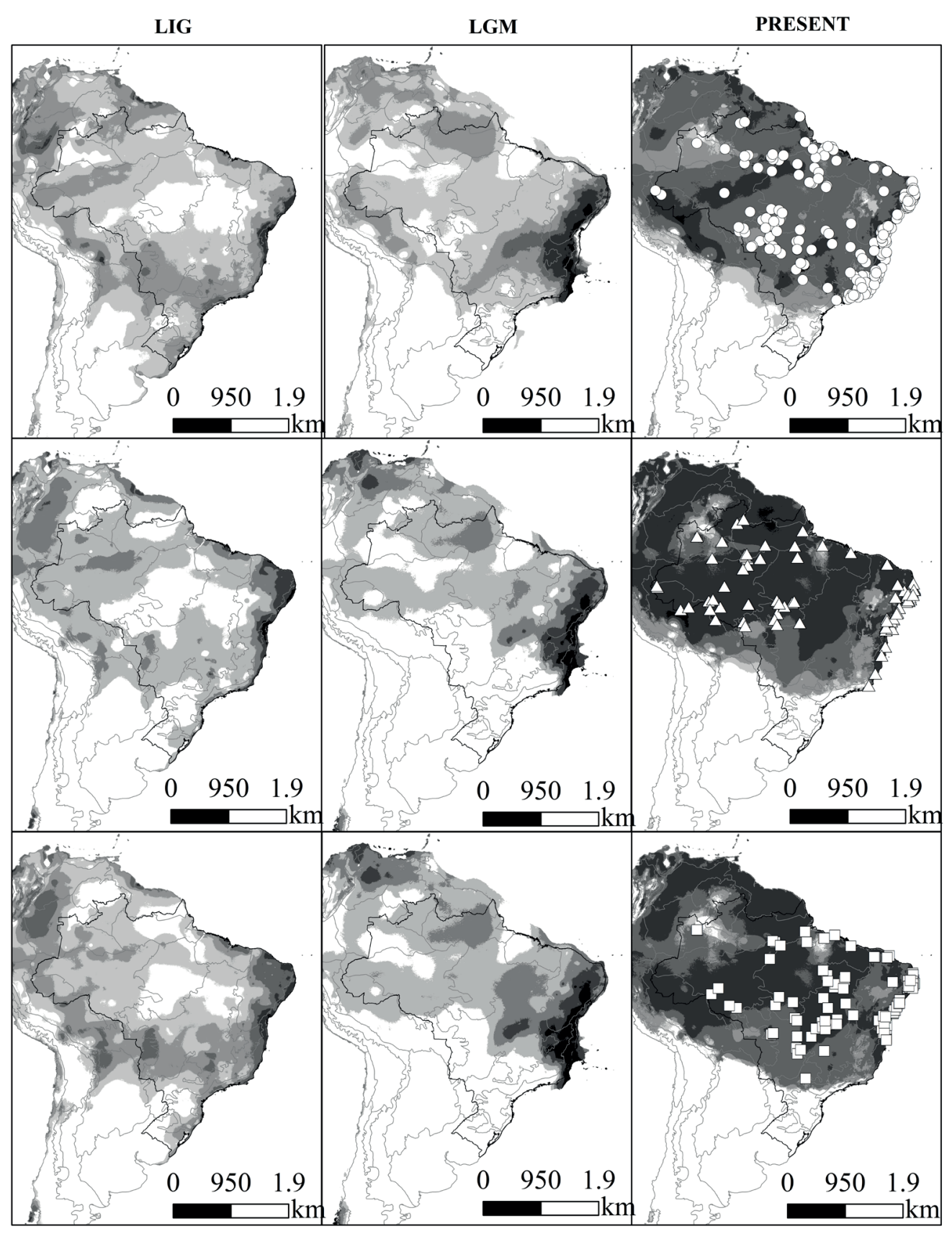

\section{Legend}

Species
$\triangle \quad$ Erythroxylum citrifolium
$\triangle \quad$ Erythroxylum mucronatum
$\square \quad$ Erythroxylum squamatum

\section{Percentiles of presence}

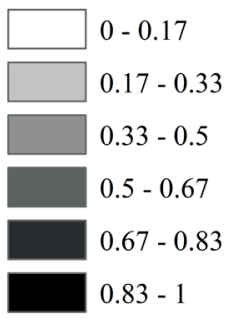

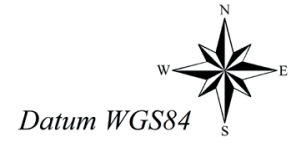

Figure 2. Miscellaneous pattern with predominance of subtropical wet vegetation under LIG conditions ( 130 Kyr BP), LGM ( 21 Kyr BP) and Present (current climate). The gray gradient represents the probability of occurrence between values of $0-1$. Low values represent less probability of occurrence and higher values, more probability. 


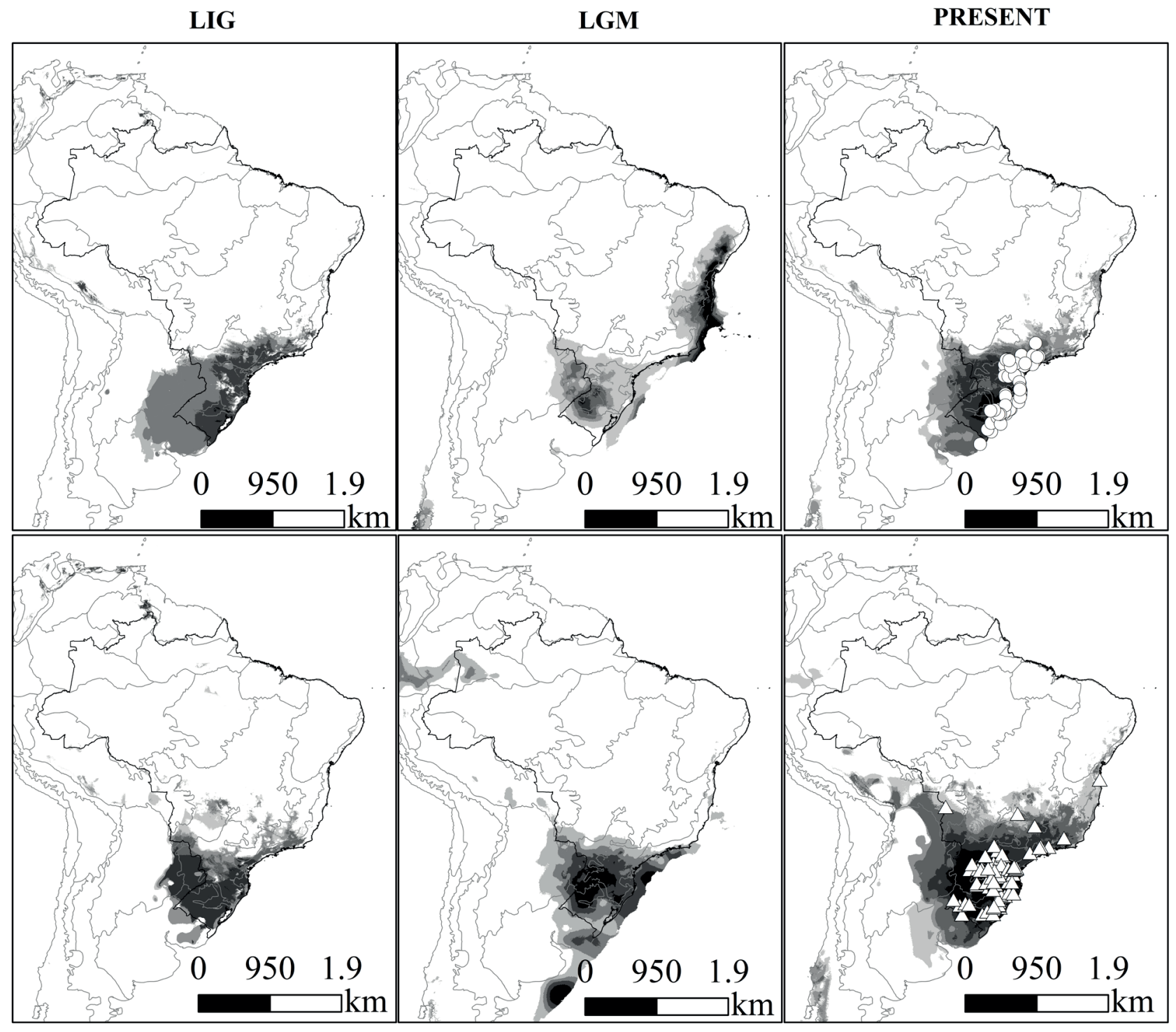

\section{Legend}

\section{Species}

Erythroxylum argentinum

$\triangle \quad$ Erythroxylum myrsinites

\section{Percentiles of presence}

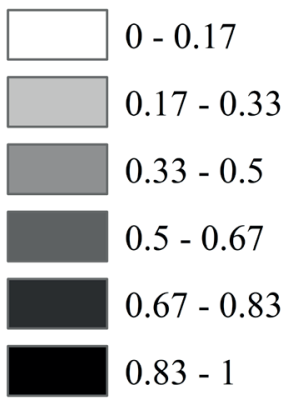

Datum WGS84

Figure 3. South Parana pattern with predominance of subtropical wet vegetation under LIG conditions ( 130 Kyr BP), LGM ( 21 Kyr BP) and Present (current climate). The gray gradient represents the probability of occurrence between values of 0-1. Low values represent less probability of occurrence and higher values, more probability. 


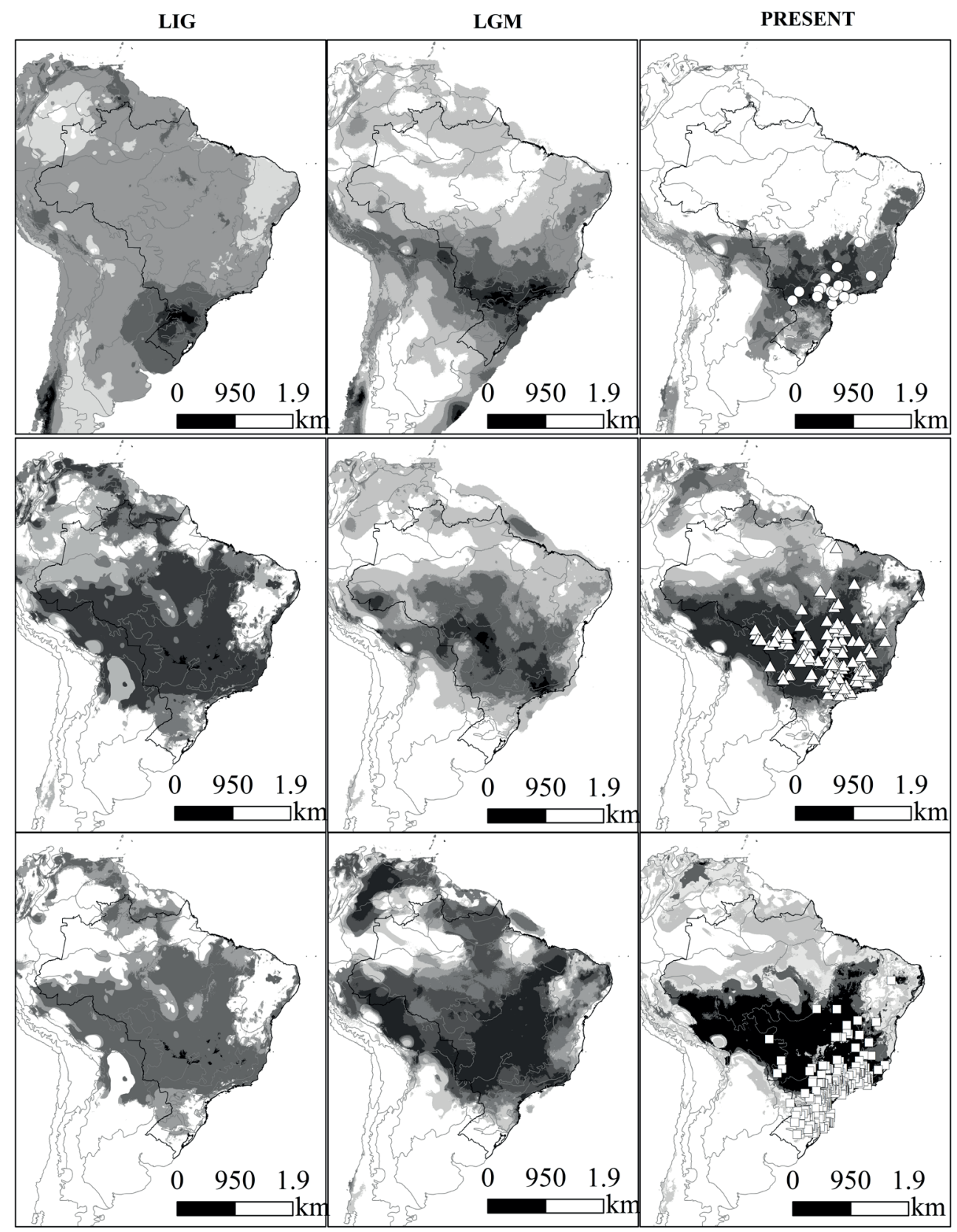

\section{Legend}

Species

$\begin{array}{ll}\triangleright & \text { Erythroxylum buxus } \\ \triangle \quad \text { Erythroxylum daphinites } \\ \square \quad \text { Erythroxylum deciduum }\end{array}$

\section{Percentiles of presence}

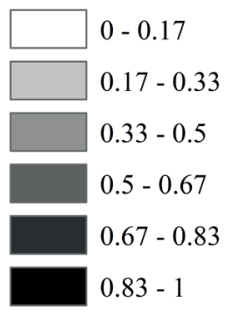


northeastern and southeastern coasts and then extending to the central-west and neighboring countries.

\section{Discussion}

The expansions and contractions of areas of occurrence examined in the present study were not clear for all of the species analyzed. The discontinuities observed can be explained by the temporal distances between the scenarios analyzed, making it difficult to portray a more refined scale. The population dynamics proposed by the models and by Rull (2009), however, can provide an overview of the development of the paleovegetation in the study area and guide future studies.

The analyses of the influences of humid and dry climatic conditions have been used to explain the theoretical frameworks of paleodistributions, and can be divided into two main groups: those that focus on rainforest dynamics (Gentry 1982; 1988; Auler et al. 2004; Haffer 1969; 2008) and those that focus on semiarid savanna environments (Cerrado and Caatinga) (Behling et al. 2000; Pennington et al. 2009).

Tropical rain forests, represented here by the Amazonian, Miscellaneous, and South Paraná patterns, showed population retractions concentrated in small areas in the central-west (Amazonian and Miscellaneous patterns) and northeast (Amazonian, Miscellaneous, and South Paraná patterns), as seen during LIG. Similar areas were identified by Gentry (1982; 1988), Auler et al. (2004), and Hoorn et al. (2010). Although very similar to those suggested by these authors, they are poorly detailed in the literature and should be better explored.

During the LGM, populations expanded toward their current areas of occurrence, and it was possible to delimit small refuges (symbolized by darker spots) in the Miscellaneous and Amazonian patterns, as indicated by Haffer $(1969 ; 2008)$ in coincident with regions at the northern edge of the Amazon Basin. Contrary to what that author suggested, however, the models imply that the rainforest continuum in the Amazon region was not fragmented due to extreme aridity, as supported by the paleoecological data of Marchant et al. (2009) and Hoorn et al. (2010). According to VanDerWal et al. (2009), in a similar study of Australian rain forests, the climatic variations that occurred during the LGM did not uniformly affect all of the different rainforest types. As we suggested, upland forests were found to be stable and could survive long periods of drought. The species of the Amazonian and Miscellaneous (E. mucronatum) patterns occur in this vegetative type, a fact that may explain the maintenance of their population areas during the LGM.

The models generated for the South Parana pattern, under all scenarios, suggested possible disjunctions, with large numbers of areas of occurrence in the subtropical region, but smaller numbers of tropical areas and near the northeastern coast. This disjunction did not exist for all species in that pattern, as E. argentinum was recorded only in southern and southeastern Brazil, as described by BFG (2015) and Flora do Brasil 2020. Despite the absence of predicted disjunctions in the northeast for $E$. argentinum and in the north during the LIG for both species, and in the LGM only for E. myrsinites, the distribution observed in the southern part of that country coincided with what was expected for paleoclimatic variations in the area, as already described by Thompson et al. (2011).

Dry vegetation (Seasonal Dry pattern) retracted during the LIG, and its distribution shifted to the central-west, north, and south. The decrease in the area of occupation of dryland species was also described by Behling et al. (2000), Pennington \& Dick (2004), Thompson et al. (2011), and Baker \& Fritz (2015). During the LIG, E. buxus was the only species that occurred throughout the country, while E. deciduum was displaced, and showed a more restricted distribution along the southern coast. According to Perez et al. (2016), the LIG was the most favorable period for the formation of small refuges of diversity for tropical dry vegetation due to increased rainfall. This fragmentation was more evident with $E$. daphinites than with E. deciduum.

During the LGM, the sites of occurrence of the dry vegetation taxa (Seasonal Dry patterns) of the current Chacoan domain overlapped with rain forest taxa of the Miscellaneous pattern (Auler et al. 2004; Werneck et al. 2011; Collevatti et al. 2012). This approximation of dry vegetation and wet forests also occurred in the northern portion of the Caatinga, as evidenced by the Amazonian, Miscellaneous and Seasonal Dry patterns. This mixture of vegetation types has been well documented in the literature (Ledru et al. 1998; Colinvaux et al. 2000; Auler et al. 2004; Pennington et al. 2009) and helps explain the current presence of rain forests on mountain tops in the northeastern region of Brazil. The species that constitute the Miscellaneous pattern are an example of this distribution, currently centered in mountainous areas in the Northeast.

Most humid vegetation Erythroxylum species occur in southern Bahia and northern Maranhão. Southern Bahia is cited by Carnaval \& Moritz (2008) as an extensive and historically stable area of Atlantic Rainforest. Additionally, according to BGF (2015) and Flora do Brasil 2020, Bahia has the largest number of species of Erythroxylum (56), six of which are widely distributed, 32 are endemic to Brazil, and 13 are restricted to that state. Relationships between historically stable areas during the Pleistocene and high values of richness and endemism were also found by Feng et al. (2016) and $\mathrm{Ma}$ (2016) for species of different botanical families in a similar type of study undertaken in China.

During the LIG, five species (Erythroxylum amazonicum, E. argentinum, E. citrifolium, E. mucronatum and E. squamatum) had very favorable areas of occurrence near the coast in northeastern Brazil. The high species richness of that region at that time indicates that the center of origin of the 
genus was in the Neotropics. Oltman (1968), hypothesized that Erythroxylum originated in Africa. In that scenario, the expansion of its species along the northeastern and southeastern coastal areas of Brazil (connected to Africa in the supercontinent Gondwana at that time) indicates that the colonization of the genus in South America followed the Brazilian coast. These patterns are therefore indicative of three distinct species dispersal routes: tropical moist, subtropical moist (both exhibiting outward distribution expansions), and semiarid region (occurring both in the tropical and subtropical regions and concentrated in the interior of Brazil).

To understand the diversity found in the tropics, it is important to understand how diversity was distributed during the last glacial maximum (Behling et al. 2000; OttoBliesner et al. 2006; Pennington et al. 2009) which would allow us to predict how changes in the biota due to the expansion of dry vegetation types influenced areas now occupied by rainforest. The similarity of environmental conditions then to the current warming of the tropics may help predict which species will be favored by this expansion and which may become extinct in Brazil. In the present study, the species that stood out were Erythroxylum buxus of the Seasonal Dry pattern (expansion) and E. kapplerianum of the Amazonian pattern (retraction).

\section{Acknowledgements}

To the Coordination for the Improvement of Higher Education Personnel (CAPES) for the doctoral scholarship granted to the first author; to the project CAPES / PROCAD 157/2007, coordinated by Professor Francisca Soares de Araújo, for the financial support and sandwich scholarship to the University of Campinas (UNICAMP) for discussion and preparation of part of the thesis; Francisca Soares de Araújo, Fernando Roberto Martins and Maria Iracema Bezerra Loiola thanks CNPq for the scholarship granted.

\section{References}

Anderson RPD, Lew A, Peterson T. 2003. Evaluating predictive models of species distributions: criteria for selecting optimal models. Ecological Modelling 162: 211-232.

Antonelli A, SanMartin I. 2011. Why are there so many plant species in the Neotropics? Taxon 60: 403-414.

Arakaki M, Christin PA, Nyffeler R, et al. 2011. Contemporaneous and recent radiations of the world's major succulent plant lineages. Proceedings of the National Academy of Sciences 108: 8379-8384.

Auler AS, Wang X, Edwards RL, et al. 2004. Quaternary ecological and geomorphic changes associated with rainfall events in presently semiarid northeastern Brazil. Journal of Quaternary Science 19: 693-701.

Baker PA, Fritz SC. 2015. Nature and causes of Quaternary climate variation of tropical South America. Quaternary Science Reviews 124: 31-47.

Batalha HF, Miyaki CY. 2011. Filogeografia da Mata Atlântica. Revista Brasileira de Biologia, Vol. Especial Biogeografia 31-34.

Behling H, Arz HW, Pätzold J, Wafer G. 2000. Late quaternary vegetational and climate dynamics in northeastern Brazil, inferences from marine core GeoB 3104-1. Quaternary Science Review 19: 981-994.
Bennike O, Bocher J. 1990. Forest-Tundra neighbouring the North Pole: Plant and insect remains from the Plio-Pleistocene Kap K0benhavn Formation, North Greenland. Arctic 43: 331-338.

BFG - The Brazil Flora Group. 2015. Growing knowledge: an overview of seed plant diversity in Brazil. Rodriguésia 66: 1085-1113.

Bueno ML, Pennington TR, Dexter KG, et al. 2016. Effects of Quaternary climatic fluctuations on the distribution of Neotropical savanna tree species. Ecography 39: 1-12.

Carnaval AC, Moritz C. 2008. Historical climate modeling predicts patterns of current biodiversity in the Brazilian Atlantic forest. Journal of Biogeography 35: 1187-1201.

Colinvaux PA, Oliveira PE, Bush MB. 2000. Amazonian and neotropical plant communities on glacial time-scales: The failure of the aridity and refuge hypotheses. Quaternary Science Review 19: 141-169.

Collevatti RG, Terribile LC, Oliveira G, et al. 2012. Drawbacks to palaeodistribution modeling: the case of South American seasonally dry forests. Journal of Biogeography 40: 345-358.

Diniz-Filho JAF, Bini LM, Rangel TF, et al.. 2009. Partitioning and mapping uncertainties in ensembles of forecasts of species turnover under climate change. Ecography 32: 897-906.

Eiten G. 1972. The cerrado vegetation of Brazil. Botanical Review 38: 139-148.

Elith J, Phillips JS, Hastie T, Dudık M, Chee YE, Yates CJ. 2011. A statistical explanation of MaxEnt for ecologists. Diversity and Distributions 17: 43-57.

Fawcett T. 2003. ROC graphs: notes and practical considerations for data mining researchers. Palo Alto, HP Laboratories.

Feng G, Mao L, Sandel B, Swenson NG, Svenning JC. 2016. High plant endemism in China is partially linked to reduced glacial-interglacial climate change. Journal of Biogeography 43: 145-154.

Flora do Brasil 2020 em construção. Rio de Janeiro, Jardim Botânico do Rio de Janeiro. http://floradobrasil.jbrj.go v.br/ 09 Feb 2017.

Gentry AH. 1982. Neotropical floristic diversity: phytogeographical connections between Central and South America, Pleistocene climatic fluctuations, or an accident of the Andean orogeny? Annals Missouri Botanical Garden 69: 557-593.

Gentry AH. 1988. Changes in plant community diversity and floristic composition on environmental and geographical gradients. Annals Missouri Botanical Garden 75: 1-34.

Haffer J. 1969. Speciation in amazonian forest birds. Science 165: 131-137.

Haffer J. 2008. Hypotheses to explain the origin of species in Amazonia. Brazilian Journal of Biology 68: 917-947.

Haffer J, Prance GT. 2001. Climatic forcing of evolution in Amazonia during the Cenozoic: On the refuge theory of biotic differentiation. Amazoniana 16: 579-608.

Hijmans RJ, Cameron SE, Parra JL. 2005. Worldclim global climate layers Version 1.4. www.worldclim.org/ 09 Feb. 2017.

Hoorn C, Wesselingh FP, Steege H, et al. 2010. Amazonia through time: Andean uplift, climate change, landscape evolution and biodiversity. Science 330: 927-931.

Hughes CE, Pennington RT, Antonelli A. 2013. Neotropical plant evolution: assembling the big picture. Botanical Journal Linnean Society 171 : $1-18$.

IBGE - Instituto Brasileiro de Geografia e Estatística. 2017. Mapas interativos. http://mapas.ibge.gov.br/ 09 Feb 2017.

Ledru MP, Bertaux J, Sifeddine A, Suguio K. 1998. Absence of Last Glacial Maximum records in lowland tropical forests. Quaternary Researcher 49: 233-237.

Lima-Ribeiro MS, Diniz-Filho JAF, 2012. Modelando a distribuição geográfica das espécies no passado: uma abordagem promissora em paleocologia. Revista Brasileira de Paleontologia 15: 371-385.

Loiola MIB. 2001. Revisão taxonômica de Erythroxylum P. Browne sect. Rhabdophyllum O.E.Schulz (ErythroxylaceaeKunth). PhD Thesis, Universidade Federal Rural de Pernambuco, Recife.

Ma Z. 2016. The effects of climate stability on northern temperate forests. PhD Thesis, Aahus University, Aahus.

Marchant R, Cleef A, Harrison SP, et al. 2009. Pollen-based biome reconstructions for Latin America at 0,6000 and 18000 radiocarbon years ago. Climate of the Past 5: 725-767. 


\section{Luciana Silva Cordeiro, Francisca Soares de Araújo, Ingrid Koch,André Olmos Simões, Fernando Roberto Martins and Maria Iracema Bezerra Loiola}

Marco-Junior P, Siqueira MF. 2009. Como determinar a distribuição potencial de espécies sob uma abordagem conservacionista? Megadiversidade 5: 65-76.

Mittelbach GG, Schemske DW, Cornell HV, et al. 2007. Evolution and the altitudinal diversity gradient. Ecological Letters 10: 315-331.

Morrone JJ. 2014.Biogeographical regionalization of the Neotropical region. Zoot. 3782: 1-110.

Muñoz MES, Giovanni R, Siqueira MF, et al. 2009. openModeller: a generic approach to species' potential distribution modelling. GeoInformatica 15: 111-135.

Nix HA. 1986. A biogeographic analysis of Australian elapid snakes. In: Longmore R. (ed.) Atlas of elapid snakes of Australia. Australian Flora and Fauna Series Number 7. Canberra, Australian Government Publishing Service. p. 4-15.

Oltman O. 1968. Die pollen morphologie der Erythroxylaceae und ihresystematischebedeutung. Berichte der Deutschen Botanischen Gesellschaft 81: 505-511.

Otto-Bliesner BL, Marshall SJ, Overpeck JT, Miller GH, Hu H. 2006. Simulating arctic climate warmth and icefield retreat in the last interglaciation. Science 311: 1751-1753.

Pennignton RT, Dick CW. 2004. The role of immigrants in the assembly of the South American rainforest tree flora. Philosophical Transactions of the Royal Society 359: 1611-1622.

Pennignton RT, Lavin M, Oliveira-Filho A. 2009. Woody plant diversity, evolution, and ecology in the tropics: Perspectives from seasonally dry tropical forests. Annual Review of Ecology, Evolution, and Systematics 40: 437-457

Perez MF, Bonatelli IAS, Moraes EM, Carstens BC. 2016. Model-based analysis supports interglacial refugia over long-dispersal events in the diversification of two South American cactos species. Heredity 116: 550-557.

Phillips SJ, Anderson RP, Schapire RE. 2006. Maximum entropy modeling of species geographic distributions. Ecological Modeling 190: 231-259.

Plowman T, Hensold N. 2004.Names, types and distribution of Neotropical species of Erythroxylum (Erythroxylaceae). Brittonia 56: 1-53.

Portillo-Quintero CA, Sánchez-Azofeifa GA. 2010. Extent and conservation of tropical dry forests in the Americas. Biological Conservation 143: 144-155.

Prado DE, Gibbs PE. 1993. Patterns of species distributions in the dry seasonal forests of South America. Annals of the Missouri Botanical Garden 80: 902-927.

Rull V. 2009. Microrefugia. Journal of Biogeography 36: 481-484.

Schulz OE. 1907. Erythroxylaceae. In: Engler A. (ed.) Das Pflanzenreich 4: 1-164.

Soberón J, Peterson AT. 2005.Interpretation of models of fundamental ecological niches and species distributional areas. Biodiversity Information 2: 1-10.

speciesLink. 2017. Sistema de informação distribuído para coleções biológicas. www.splink.cria.org.br/ 09 Feb 2017.

Thiers B. 2017. [Continuously Updated]. Index Herbariorum: a global directory of public herbaria and associated staff. New York Botanical Garden's Virtual Herbarium. http://sweetgum.nybg.org/ih/. 09 Feb 2017.

Thompson LG, Mosley-Thompson E, Davis ME, Brecher HH. 2011. Tropical glaciers, recorders and indicators of climate change, are disappearing globally. Annals of Glaciology 52: 23-34.

VanDerWal J, Shoo LP, Whilliams SE. 2009. New approaches to understanding late Quaternary climate fluctuations and refugial dynamics in Australian wet tropical rain forests. Journal Biogeography 36: 291-301.

Warren DL, Glor RE, Turelli M.2010. ENMTools: a toolbox for comparative studies of environmental niche models. Ecography 33: 607-611.

Werneck FP, Costa GC, Colli GR, Prado DE, Sites Jr. JW. 2011. Revisiting the historical distribution of Seasonally Dry Tropical Forests: new insights based on palaeodistribution modeling and palynological evidence. Global Ecology and Biogeography 20: 272-288.

Willig MR, Kaufman DM, Stevens RD. 2003. Latitudinal gradients of biodiversity: Pattern, Process, Scale, and Synthesis. Annual Review of Ecology, Evolution, and Systematics 34: 273-309. 